Journal of Money and Economy

Vol. 15, No. 2, Spirng 2020

pp. $151-180$

DOI: $10.2952 /$ jme.15.2.151

Original Research Article

\title{
The Impact of Domestic and Foreign Monetary Policy on Iran's economy: Global Modeling
}

\author{
Simin Akbari Dehbaghi* \\ Abdol Majid Ahangari \\ Seyed Aziz Arman ${ }^{\dagger}$
}

Received: 9 Oct 2019

Approved: 15 Mar 2020

One of the striking features of the business cycles is the patterns of co-movement of output, inflation, interest rates, and real equity prices across countries. This paper empirically examines the effects of domestic and foreign monetary policies on Iran's macroeconomic variables (including real production, inflation, short-term interest rate, and real exchange rate) using quarterly data over the 1996Q1-2015Q4 period and a global vector auto-regression model (GVAR) for Iran, the largest trading partners of Iran including China, India, Russia, South Korea, Turkey, the European Union, and the United State. The results of domestic monetary policies on Iran's macroeconomic variables illustrate a form of Price Puzzle on how monetary policy shocks affect inflation in Iran. The effects of the positive shocks of domestic interest rate on real GDP in Iran is negative. Iran's real exchange rate response to the positive shock of domestic interest rates is negative and significant. The results regarding the impact of the foreign monetary policies on Iran's macroeconomic variables illuminate that only the effects of a positive shock to China's interest rate are significant and negative on Iran's inflation. Besides, there is a significant independency of Iran's real GDP to the monetary policy shocks of the other trading partners of Iran. Also, the response of Iran's real exchange rate to positive monetary shocks in the EU and Turkey is at a positive and significant level. The results indicate that due to the closed economic structure of Iran, global economic crises that lead to a recession in other countries have had the least impact on the Iranian economy.

Keywords: Global Spillover, Global VAR, Monetary Policy.

JEL Classification: E43, E44, E52, E65, F42, F47

\footnotetext{
${ }^{*}$ Faculty of Economic and Social Sciences, Shahid Chamran University of Ahvaz, Ahvaz, Iran; simin_akbari2000@yahoo.com

$\dagger$ Faculty of Economic and Social Sciences, Shahid Chamran University of Ahvaz, Ahvaz, Iran (Corresponding Author); saarman2@yahoo.com

$¥$ Faculty of Economic and Social Sciences, Shahid Chamran University of Ahvaz, Ahvaz, Iran; a_m_ahamgari@yahoo.com
}

This paper is part of a $\mathrm{PhD}$ dissertation written by Simin Akbari Dehbaghi under supervisory of Seyed Aziz Arman and Abdol Majid Ahangari. 


\section{Introduction}

One of the main features of business cycles in countries is the patterns of comovement of GDP, inflation, interest rates, and the price of real assets. These combined movements have been widely observed in the last two decades as a result of the growing economic and financial integration between countries. The combined movement of real GDP in countries has been studied by several researchers; For example, Gregory et al. (1997) used Kalman filtering and dynamic factor analysis to provide an empirical analysis of the relationship between total production, consumption, and investment for the G-7 countries. Other similar analyzes have been performed by Canova and Marrinan (1998), Lumsdaine and Prasad (2003), and Kose et al. (2003).

International transfers of business cycles through various channels affect the domestic economy. The international transfers can be the result of global shocks (such as changes in oil prices), unobserved global factors (such as technological advances or regional political developments), and can even be the result of domestic shocks related to a particular country. So, to understand the effect of the above shocks on the domestic economy, modeling the country's economy in the framework of a global model is required. Despite the growing share of international studies in the field of global modeling of countries, such a study has not been conducted about the domestic economy.

In the international studies that have been done for the global modeling of the economies, the need for the inclusion of a large number of countries and internal and external variables in the process of global modeling is a major problem in the study of the spillover effects of global variables on the domestic economies. For example, in this context, unobserved operating models with a large number of macroeconomic variables, introduced by Stoke and Watson (2002) or dynamic operating models developed by Forni and Reichlin (1998) and Forni et al. (2000), in which using the principal components and a small number of coefficients, the experimental relationships of a large number of variables can be used; But determining the coefficients of such models is often troublesome, especially when we want to have an economic interpretation of them (Dees and et al., 2007). Accordingly, new international studies use the global vector autoregressive (GVAR) model, first introduced and expanded by Pesaran et al. (2004), to model the global economies of countries (Belke and Osowski, 2016; Ludovic, et al, 2015; Dragomirescu-Gaina and Philippas, 2015; Ricci-Risquete and RamajoHernández, 2014; Gurara and Mthuli, 2013; Khezri, Zulkhibri, and Ghazal, 2019). This model has largely overcome the problems of previous models with 
comprehensive global modeling of countries and examining the relative importance of each of the various sources of common trends and comovements in macroeconomic variables and thus is used in this study.

From a theoretical point of view, spillover effects of shocks from a country or region on other countries can be driven by various transmission channels. In Mundell-Flemming-Dornbusch models and DSGE models of free standard economy, the effects of shock spillovers from one country or region on other countries are done through the trade sector channel of the economy. Accordingly, one of the objectives of the present study is to determine the relative trading share of different countries to the Iranian economy through the trade channels, so that by calculating the weights matrix of different countries, calculated by the ratio of total exports and imports of each country to Iran, the relative share of each country in the trade with Iran is specified. In the next step, to study the application of global modeling to study internal and external shocks on Iran's economy, using the variables specified by the theoretical foundations (including real exchange rate, inflation, interest rate, and real production) and the Global Vector Autoregressive (GVAR) introduced by Pesaran, et al. (2004), the effects of domestic and foreign monetary policies on Iran's macroeconomic variables have been investigated.

This paper is organized as follows: Section 2 describes theoretical foundations; Section 3 investigates empirical literature; Section 4 describes the GVAR estimation methodology. Section 5 provides analytical discussions on global economic shocks. Finally, Section 6 offers our conclusion.

\section{Theoretical Foundations}

International spillovers and the reciprocal effects of economic policies have been studied in recent years by many international studies, in which the effects of monetary policies of different countries on each other is one of the issues studied in this area. Various empirical studies have examined the impact of the expansionary monetary policy of the foreign economy on the domestic economies of the world. According to international studies, the expansionary monetary policy pursued by a foreign economy leads to external demand for domestic goods increases, which is reflected in the increase of domestic exports and the promotion of domestic production through the IS curve of an open economy (the effect of attracting revenue or the demand channel); Thus, in the case of countries that keep their exchange rates stable against foreign currencies, the trade channel has indicated that domestic production must move in the same direction as foreign production through increased foreign demand. However, in countries with flexible exchange rates, the domestic 
exchange rate rises after foreign financial expansion, and the value of the national currency decreases, moving against the foreign exchange rate. This can worsen the balance of domestic trade and reduce domestic production, exchange rate adjustments make the demand channel ineffective, and the effects of policy spillovers on trade are ambiguous (Dornbusch, 1980; Gali and Monacelli, 2005; Lubik and Schorfheide, 2007; Cwik et al., 2011). Which of the effects dominates in the case of a flexible exchange rate regime, will depend on the degree of openness of the domestic economy, the elasticity of substitution between domestic and foreign goods, and the intertemporal elasticity of substitution that captures the degree of consumption smoothing occurring via intratemporal trade. A review of studies conducted at the international level on the effect of foreign monetary policy on the domestic economy shows that, depending on the structural conditions governing the country's economy, foreign monetary policy can be channeled. Appear in the domestic economy, and not considering global modeling of the economies of countries can lead to ignoring some of the above channels, for example, monetary policy shocks can be independent through the financial channel. Transfer internationally from the level of trade integration and exchange rate regime. Standard open-economy DSGE models indicate that if a foreign country is a large open economy, a decrease in foreign interest rates can indirectly reduce domestic interest rates along with a decrease in global interest rates (Svensson and van Wijnbergen, 1989; Gali and Monacelli, 2005). Besides, the financial channel can operate with the global banking sector. A decrease in foreign interest rates reduces the cost of foreign currency loans and increases credit demand (Bernanke and Gertler, 1995). An increase in the domestic exchange rate, which may be caused by the expansion of foreign currency, can relieve the debt burdens of existing foreign currency loans, which has a positive effect on wealth and improves borrowers' creditworthiness (Bruno and Shin, b2015).

Eventually, credit supply increases because foreign banks can get their funds from their head offices at a lower cost (Cetorelli and Goldberg, 2012). Thus, the foreign monetary policy promotes the growth of domestic credit and capital inflows by improving financing conditions. This intensifies domestic investment and leads to international symmetric movements in GDP (Devereux and Yetman, 2010). However, persistently low cost of external financing can also increase risk-taking and credit growth in capital flows (Bruno and Shin, 2015a; Rey, 2015).

From this point of view, the theoretical and empirical analysis of the impact of foreign monetary policy on the domestic economy can be complex and 
multidimensional; therefore, such an issue should be addressed in a global modeling framework, a problem that is not investigated in studies conducted on Iran's economy.

\section{Empirical Literature}

Many empirical studies focus on monetary policy shocks and their channels of transmission. By applying small-scale structural VAR models, Kim (2001) found that the expansionary monetary policy of the United States increased output in the G-6. Canova (2005) examined the effects of US monetary policy shocks on Latin American countries, especially those that were keeping their exchange rates stable against the US dollar, in which transfers through the financial channel through interest rate responses. Applying a Bayesian GVAR approach, Feldkircher and Huber (2016) confirmed the discovery of large spillovers from US monetary policy on the product in large groups of countries through the financial and trade channels. Based on these findings, the effects in Latin America are particularly strong.

Some recent works have taken a closer look at the role of the prevailing conditions in the country's economy in the extent of the effects of the spillovers of US monetary policy, and different results have been obtained. Using the GVAR approach, Georgiadis (a2015) found that the effects of the US monetary policy spillovers on output were stronger in countries with weaker financial development, lower exchange rates, and flexible labor markets. Aizenman et al. (2016) found that financial spillovers are greater than monetary policy in the United States and other countries in economies with variable exchange rates and higher fiscal openings. Finally, Dedola et al. (2016) using a BVAR approach found that US monetary policy shocks have stronger effects on emerging economies than advanced ones; But those characteristics of the country such as exchange rate regime, income level, trade, and financial openness cannot systematically explain the differences between countries.

Another series of articles describes the transmission of common euro area monetary policy shocks to monetary union member states (Peersman, 2004; Boivin et al., 2008; Barigozzi et al). The common finding of these studies is that the Euro area monetary policy is somewhat homogeneously transmitted to the product in different member states, but the answer to prices and unemployment is asymmetric.

Monetary policy spillovers to European countries outside the euro area have also attracted the attention of these studies. Using an SVAR approach, Jannsen and Klein (2011) found that the Euro area monetary policy shocks 
had significant relative effects on exchange rates and output in the five noneuro western countries. Mumtaz and Surico (2009) took a FAVAR approach and found that after an expansion of international monetary policy, the UK output increased despite the appreciation of the exchange rate. Liu et al. (2014) using a time-varying FAVAR model found that the rise in the exchange rate in the UK after a foreign interest rate shock remains significant over time, but the product response was significant only before the 90s. And then it is about zero, which may be the result of a shift from the producer to the pricing of local currency in the UK.

Eickmeier and Breitung (2006) used a dynamic coefficient model for the euro area and eight CEE countries, taking into account the countries of Central and Eastern Europe, and found that the product in most CEE countries showed a positive reaction to the shock of the euro area expansionary monetary policy, whereas the responses of inflation rates are mixed. Jiménez-Rodriguez et al. (2010) obtained comparable results when investigating structural fractures. Based on country-related FAVAR models for Hungary, Poland, and the Czech Republic, Benkovskis et al. (2011) found that after a contractionary monetary policy shock in the euro area, exchange rates in these countries fell and prices rose while real activity variables decline due to reduced foreign demand. Feldkircher (2014) and Hájek and Horváth (2015) used GVAR models to analyze the transmission of euro area interest rate shocks to large groups of non-euro area countries and found that symmetric product responses reacted more strongly in small countries than in euro area countries. Next, Horvath and Voslarova (2016) found that the amount of the Eurozone unconventional monetary policy, which was characterized by low interest rates, had positive product spillovers and uncertainty in non-euro area countries, while a weak and insignificant price and interest rate spillovers were observed.

Overall, most empirical studies have shown the effects of asymmetrical spillovers on euro area monetary policy on output in non-euro area countries, while the results for spillovers differ on prices and exchange rates. Thus, many existing empirical studies focus on the two-country model, which examines a country outside the euro area at the same time and therefore does not account for the potential spillovers effects between countries outside the euro area (Mumtaz and Surico, 2009; Benkovskis et al., 2011; Jiménez-Rodriguez et al., 2010). Such an approach has been questioned by Georgiadis (b2015); He showed that spillover estimates from bilateral models are less accurate than multi-country models because they systematically underestimate the magnitude of spillover effects in the presence of higher-order spillovers. Other studies use multi-country models but consider only product responses and 
prices (Eickmeier and Breitung, 2006; Feldkircher, 2014; Ha’jek and Horv'ath, 2015).

Also, unlike empirical studies on US monetary policy shocks, most studies on the international transfer of monetary policy in the euro area have not been conducted to determine the relative importance of the trade and financial channels or the role of country characteristics in the size of spillovers effects. Besides, a recent study by Bluwstein and Canova (2015), analyzed spillovers from unconventional euro area monetary policy to non-euro area countries using the mixed-frequency BVAR. The authors find that the shocks of the unconventional monetary policy of the euro area are transmitted through the financial channel to countries outside the euro area, not the trade channel and that countries with more comprehensive and developed financial markets are exposed to stronger product and risk spillovers.

\section{The Global VAR (GVAR) Approach}

To investigate the research method of the present study, the GVAR model to analyze the mechanisms of international transfers and relate it to models with invisible factor, assume that $\mathrm{N}+1$ country (or region) exists in the global economy and with $i=0,1, \ldots, N$ are indexed. The aim is to model several country-specific macroeconomic variables such as real GDP, inflation, interest rates, and exchange rates on the $\mathrm{X}_{i t}$ vector at $t=1,2, \ldots, T$ and in $\mathrm{N}+$ 1 countries. Given the general nature of the interdependencies that may exist in the world economy, it is quite desirable that all country-specific variables $\mathrm{X}_{i t}, i=0,1, \ldots, N$, and the observed global factors (such as oil prices) be used endogenously. The following general operating model provides a good starting point for us and allows us to relate the GVAR approach to the operating models used in the previous literature to analyze the economies of the G-7 countries.

We represent the observed global factors with the $m_{d} \times 1$ vector $d_{t}$, and the unobserved global factors the $\mathrm{m}_{f} \times 1$ vector $\mathrm{f}_{\mathrm{t}}$, and assume that:

$x_{i t}=\delta_{i 0}+\delta_{i 1} t+\Gamma_{i d} d_{t}+\Gamma_{i f} f_{t}+\xi_{i t}$ for $i=0,1, \ldots, N, t=1,2, \ldots, T$

Where $\Gamma_{i}=\left(\Gamma_{i d}, \Gamma_{i f}\right)$ is the matrix $k_{i} \times m$ of the loading factors and $m=$ $m_{d}+m_{f}, \xi_{i t}$ is a $k_{i} \times 1$ vector that represents country-specific effects, including $\mathrm{X}_{\mathrm{it}}$ lagged values or country-specific dummies variables that depict institutional and political developments; $\delta_{i 0}$ and $\delta_{i 1}$ are coefficients of algebraic values, which here are intercepts and linear trends. The vector of global variables observed can include international variables such as the price 
of oil or other commodities, global spending on $R \& D$, or other global technology indicators such as the number of international patents registered in the United States.

The unit root and the cointegration properties of $\mathrm{X}_{\mathrm{it}}, i=0,1, \ldots, N$, can be adapted if the global coefficients $\mathrm{h}_{t}=\left(d_{t}^{\prime}, f_{t}^{\prime}\right)^{\prime}$ or the country-specific coefficients, $\xi_{i t}$, are allowed to have unit roots. More specifically, we assume that

$\triangle h_{t}=\Lambda(L) \eta_{t}, \eta_{t} \sim \operatorname{IID}\left(0, I_{m}\right)$

$\triangle \xi_{i t}=\Psi_{i}(L) v_{i t}, v_{i t} \sim \operatorname{IID}\left(0, I_{k_{i}}\right)$

Where $\mathrm{L}$ is the lag operator and

$\Lambda(L)=\sum_{\ell=0}^{\infty} \underset{m \times m}{\Lambda_{\ell} L^{\ell}}, \quad \Psi_{i}(L)=\sum_{\ell=0}^{\infty} \begin{gathered}\Psi_{i \ell} L^{\ell} \\ k_{i} \times k_{i}\end{gathered}$

The coefficient matrices, $\Lambda_{l}$ and $\Psi_{i l}, i=0,1, \ldots, N$, are absolute summable, so that $\operatorname{Var}\left(\Delta f_{t}\right)$ and $\operatorname{Var}\left(\Delta \xi_{i t}\right)$ are bounded and positive definite, and $\left[\Psi_{i}(L)\right]^{-1}$ exists. In particular, we require that

$\operatorname{Var}\left(\triangle \xi_{i t}\right)=\sum_{\ell=0}^{\infty} \Psi_{i \ell} \Psi_{i \ell}^{\prime} \leq K<\infty$

Where $\mathrm{K}$ is a fixed bounded matrix.

First differencing (1) and using (3) we have

$\left[\Psi_{i}(L)\right]^{-1}(1-L)\left(x_{i t}-\delta_{i 0}-\delta_{i 1} t-\Gamma_{i d} d_{t}-\Gamma_{i f} f_{t}\right)=v_{i t}$.

Using the approximation

$(1-L)\left[\Psi_{i}(L)\right]^{-1} \approx \sum_{\ell=0}^{p_{i}} \Phi_{i \ell} L^{\ell}=\Phi_{i}\left(L, p_{i}\right)$,

We obtain the following approximate $\operatorname{VAR}\left(p_{i}\right)$ model:

$\Phi_{i}\left(L, p_{i}\right)\left(x_{i t}-\delta_{i 0}-\delta_{i 1} t-\Gamma_{i d} d_{t}-\Gamma_{i f} f_{t}\right) \approx v_{i t}$

Without the unobserved common factor, $f_{t}$, the model for country $i^{\text {th }}$ is separated from other country models, and the model for each country can be estimated separately using the econometric techniques developed in Harbo et al. (1998) and Pesaran, Shin, and Smith (2000). Where $d_{t}$ interacts as a weak exogenous. By including an unobserved common factor, the model is quite complex and its econometric analysis using Kalman techniques will be quite difficult unless $\mathrm{N}$ is very small. When $\mathrm{N}$ is relatively large, it is a simple but 
effective alternative would be to following the study of Pesaran (2005) and representing $f_{t}$ in terms of the cross-sectional averages of country-specific variables, $X_{i t}$, and the observed common effects, $d_{t}$. To find out how to use this process, from the method used in this paper, it is first assumed that $\mathrm{k}_{i}=$ $k$ and from the same set of similar weights, $w_{j}, \mathrm{j}=0,1, \ldots, \mathrm{N}$, to accumulate country-specific relations in the relation (1) is defined, is used to obtain the following:

$\sum_{j=0}^{N} w_{j} x_{j t}=\sum_{j=0}^{N} w_{j} \delta_{j 0}+\left(\sum_{j=0}^{N} w_{j} \delta_{j 1}\right) t+\left(\sum_{j=0}^{N} w_{j} \Gamma_{j d}\right) d_{t}$ $+\left(\sum_{j=0}^{N} w_{j} \Gamma_{j d f}\right) f_{t}+\sum_{j=0}^{N} w_{j} \xi_{j t}$,

Or

$x_{t}^{*}=\delta_{0}^{*}+\delta_{1}^{*} t+\Gamma_{d}^{*} d_{t}+\Gamma_{f}^{*} f_{t}+\xi_{t}^{*}$

Also, note from (3) that

$\xi_{t}^{*}-\xi_{t-1}^{*}=\sum_{j=0}^{N} w_{j} \Psi_{j}(L) v_{j t}$

But using Lemma A.1 in Pesaran (2006), it is easily seen that for each $t$ the left-hand side of (8) will converge to zero in quadratic mean as $N \rightarrow \infty$ if (5) holds, the country-specific shocks, $V_{i j}$, are independently distributed across $\mathrm{j}$, and if the weights, $w_{j}$, satisfy the atomistic conditions

(i): $w_{j}=O\left(\frac{1}{N}\right)$, (ii): $\sum_{j=0}^{N}\left|w_{j}\right|<K$, (iii): $\sum_{j=0}^{N} w_{j}=1$

Where $\mathrm{K}$ is a fixed constant. Under these conditions (for each $\mathrm{t}$ )

$\xi_{t}^{*}-\xi_{t-1}^{*} \stackrel{q . m}{\rightarrow} 0$

and hence

$\xi_{t}^{*} \stackrel{q \cdot m}{\rightarrow} \xi^{*}$

Where $\xi^{*}$ is a time-invariant random variable. Using this result in (7) and assuming that the $\mathrm{k} \times m_{f}$ average factor loading coefficient matrix, $\Gamma_{f}^{*}$, has full column rank (with $\mathrm{k} \geq m_{f}$ ) we obtain 
$f_{t}^{q . m} \cdot\left(\Gamma_{f}^{* \prime} \Gamma_{f}^{*}\right)^{-1} \Gamma_{f}^{*}\left(x_{t}^{*}-\delta_{0}^{*}-\delta_{1}^{*} t-\Gamma_{d}^{*} d_{t}-\xi^{*}\right)$,

Which justifies using the observable vector $\left\{1, t, \mathrm{~d}_{\mathrm{t}}, \mathrm{X}_{\mathrm{t}}^{*}\right\}$ as proxies for the unobserved common factors. Substituting this result in (6), for N sufficiently large we have:

$\Phi_{i}\left(L, p_{i}\right)\left(x_{i t}-\bar{\delta}_{i 0}-\bar{\delta}_{i 1} t-\bar{\Gamma}_{i d} d_{t}-\bar{\Gamma}_{i f} x_{t}^{*}\right) \approx v_{i t}$

Where $\bar{\delta}_{i 0} \triangleleft \bar{\delta}_{i 1} \triangleleft \bar{\Gamma}_{i d}$ and $\bar{\Gamma}_{i f}$ are given in terms of $\bar{\delta}_{i 0} \triangleleft \bar{\delta}_{i 1} \triangleleft \bar{\Gamma}_{i d} \triangleleft \bar{\Gamma}_{i f} \triangleleft \delta_{0}^{*}+$ $\xi^{*} \cdot \delta_{1}^{*} \cdot \Gamma_{d}^{*}$, and $\Gamma_{f}^{*}$.

In practice, the number of countries, $N+1$, may not be significantly large, and individual countries may not be of equal importance in the global economy. Country-specific shocks may also be cross-sectionally correlated as a result of distance or transmission effects that are not completely eliminated by the factors, $d_{t}$ and $f_{t}$. Finally, $k_{i}$ means that the number of country-specific variables need not be the same. For example, some markets may not exist or may not have developed as they should in some countries. Even if we focus on the same set of variables for modeling in countries, there will be an exchange rate lower than the number of countries in the global model. The GVAR framework developed at PSW addresses these issues using the specific weights of each country, $w_{i j}$, instead of the common $w_{j}$ weights used above to construct the cross-sectional averages. In particular, instead of using the same $\mathrm{X}_{\mathrm{t}}^{*}$ in the PSW model of all countries, we use the following:

$x_{i t}^{*}=\sum_{j=0}^{N} w_{i j} x_{j t}$ with $w_{i i}=0$

With the above considerations in mind, the GVAR model of Equation (10) can be written as $\operatorname{VARX}^{*}\left(p_{i}, q_{i}\right)$ models of individual countries:

$\Phi_{i}\left(L, p_{i}\right) x_{i t}=a_{i 0}+a_{i 1} t+Y_{i}\left(L, q_{i}\right) d_{t}+\Lambda_{i}\left(L, q_{i}\right) x_{i t}^{*}+u_{i t}$

for $\mathrm{i}=0,1, \ldots, \mathrm{N}$, where for estimation purposes $\Phi_{i}\left(L, p_{i}\right) 、 \Upsilon_{i}\left(L, q_{i}\right)$ and $\Lambda_{i}\left(L, q_{i}\right)$ can be treated as unrestricted. For the empirical implementation that will follow, for each country model, we consider at most a $\operatorname{VARX^{*}}(2,2)$ specification which in its error correction form may be written as: 
$\Delta x_{i t}=c_{i 0}-\alpha_{i} \beta_{i}^{\prime}\left[\zeta_{i, t-1}-\gamma_{i}(t-1)\right]+\Upsilon_{i 0} \Delta d_{t}+\Lambda_{i 0} \Delta x_{i t}^{*}+\Upsilon_{i 1} \Delta$

$d_{t-1}+\Gamma_{i} \triangle z_{i, t-1}+u_{i t}$,

where $\mathrm{z}_{i t}=\left(x_{i t}^{\prime}, x_{i t}^{* \prime}\right)^{\prime} \cdot \zeta_{i, t-1}=\left(z_{i, t-1}^{\prime}, d_{t-1}^{\prime}\right)^{\prime}, \alpha_{i}$ is a $\mathrm{k}_{i} \times r_{i}$ matrix of rank $r_{i}$ and $\beta_{i}$ is a $\left(k_{i}+k_{i}^{*}+m_{d}\right) \times r_{i}$ matrix of rank $r_{i}$. By partitioning $\beta_{i}$ as $\beta_{i}=\left(\beta_{i x}^{\prime}, \beta_{i x *}^{\prime}, \beta_{i d}^{\prime}\right)^{\prime}$ conformable to $\zeta_{i t}=\left(X_{i t}^{\prime}, X_{i t}^{* \prime}, d_{d}^{\prime}\right)^{\prime}$, the $r_{i}$ error correction terms defined by (13) can now be written as:

$\beta_{i}^{\prime}\left(\zeta_{i t}-\gamma_{i} t\right)=\beta_{i x}^{\prime} x_{i t}+\beta_{i x *}^{\prime} x_{i t}^{*}+\beta_{i d}^{\prime} d_{t}+\left(\beta_{i}^{\prime} \gamma_{i}\right) t$

that allows for the possibility of cointegration both within $\mathrm{X}_{i t}$ and between $\mathrm{X}_{i t}$ and $X_{i t}^{*}$ it and consequently across $\mathrm{X}_{i t}$ and $\mathrm{X}_{j t}$ for $\mathrm{i} \neq \mathrm{j}$.

Once the individual country models are estimated, all the $\mathrm{k}=\sum_{i=0}^{N} k_{i}$ endogenous variables of the global economy, collected in the $k \times 1$ vector $\mathrm{X}_{\mathrm{t}}=\left(\mathrm{X}_{0 \mathrm{t}}^{\prime}, \mathrm{X}_{1 \mathrm{t}}^{\prime}, \ldots, \mathrm{X}_{\mathrm{Nt}}^{\prime}\right)^{\prime}$, need to be solved simultaneously. PSW, show how this can be done in the case where $\mathrm{p}^{i}=q^{i}=1$. In the present more general context we first re-write (12) as:

$A_{i}\left(L, p_{i}, q_{i}\right) z_{i t}=\varphi_{i t}$, for $i=0,1,2, \ldots, N$

where

$A_{i}\left(L, p_{i}, q_{i}\right)=\left[\Phi_{i}\left(L, p_{i}\right),-\Lambda_{i}\left(L, q_{i}\right)\right], z_{i t}=\left(\begin{array}{l}x_{i t} \\ x_{i t}^{*}\end{array}\right)$,

$\varphi_{i t}=a_{i 0}+a_{i 1} t+\gamma_{i}\left(L, q_{i}\right) d_{t}+u_{i t}$.

Let $\mathrm{p}=\max \left(p_{o}, p_{1}, \ldots, p_{N}, q_{0}, q_{1}, \ldots, q_{N}\right)$ and construct $A_{i}(L, p)$ from $A_{i}\left(L, p_{i}, q_{i}\right)$ by augmenting the $p-p_{i}$ or $p-q_{i}$ additional terms in powers of $L$ by zeros. Also note that:

$z_{i t}=W_{i} x_{t}, \quad i=0,1,2, \ldots, N$

where $\mathrm{W}_{i}$ is a $\left(k_{i}+k_{i}^{*}\right) \times k$ matrix, defined by the country-specific weights, $w_{i j}$.

With the above notations (15) can be written equivalently as

$A_{i}(L, p) W_{i} x_{t}=\varphi_{i t}, \quad i=0,1, \ldots, N$,

and then stack to yield the VAR(p) model in $\mathrm{X}_{\mathrm{t}}$ :

$G(L, p) x_{t}=\varphi_{t}$

Where 
$G(L, p)=\left(\begin{array}{c}A_{0}(L, p) W_{0} \\ A_{1}(L, p) W_{1} \\ \vdots \\ A_{N}(L, p) W_{N}\end{array}\right), \phi_{t}=\left(\begin{array}{c}\varphi_{0 t} \\ \varphi_{1 t} \\ \vdots \\ \varphi_{N t}\end{array}\right)$

\section{Analytical Discussions}

\subsection{Data and Model Specification}

In this article, the quarterly data over the 1996Q1-2015Q4 period is used. In addition to Iran, the largest trading partners of Iran including China, India, Russia, South Korea, Turkey, the European Union (including Austria, Belgium, France, Finland, Italy, Germany, the Netherlands, and Spain), and the United States are included in the GVAR model for providing a global model of countries. Also, the yearly data over 1996-2015 is used for calculating the weights matrix as a primary factor in the process of estimation in the GVAR model. All data are taken from the IMF's World Economic Outlook dataset. We set the vector of domestic variable $x_{i t}=$ $\left(y_{i t}, \Delta p_{i t}, \rho_{i t}^{S}, e_{i t}-p_{i t}\right)$ in country-specific models with $k_{i}=4$, where, $y_{i t}$ is the logarithm of real production, $\Delta p_{i t}$ is inflation, $\rho_{i t}^{S}$ is the logarithm of shortterm interest rate, $e_{i t}-p_{i t}$ is the logarithm of the real exchange rate. The vector of the country-specific foreign variables $x_{i t}^{*}=\left(y_{i t}^{*}, \Delta p_{i t}^{*}, \rho_{i t}^{* s}\right)$ were constructed using trade weights that are based on Pesaran et al. (2004). We compute the weights matrix of countries $w_{i j}$, using the relative amount of import and export of each country with other countries. The time-series data for the euro area was constructed by cross-section weighted averages of $y_{i t}, \Delta p_{i t}, \rho_{i t}^{S}, e_{i t}-p_{i t}$. Except for the U.S. model, all models include the country-specific foreign variables, $\mathrm{y}_{\mathrm{it}}^{*}, \Delta \mathrm{p}_{\mathrm{it}}^{*}, \rho_{\mathrm{it}}^{* \mathrm{~s}}$. In the case of the U.S. model, $e_{i t}^{*}-p_{i t}^{*}, y_{i t}^{*}$, and $\Delta p_{i t}^{*}$ is considered as weakly exogenous. Table 1 provides the weight matrix of all countries in the GVAR model. 
Table 1

Weights Matrix

\begin{tabular}{lllllllll}
\hline Country & China & India & Iran & Russian & United States & EURO & Korea & Turkey \\
\hline China & 0.000 & 0.241 & 0.176 & 0.154 & 0.395 & 0.251 & 0.410 & 0.085 \\
India & 0.045 & 0.000 & 0.075 & 0.023 & 0.042 & 0.038 & 0.034 & 0.019 \\
Iran & 0.025 & 0.063 & 0.000 & 0.011 & 0.000 & 0.024 & 0.029 & 0.050 \\
Russian & 0.054 & 0.031 & 0.048 & 0.000 & 0.029 & 0.155 & 0.037 & 0.156 \\
United States & 0.376 & 0.283 & 0.007 & 0.080 & 0.000 & 0.400 & 0.306 & 0.107 \\
EURO & 0.294 & 0.295 & 0.544 & 0.617 & 0.415 & 0.000 & 0.173 & 0.554 \\
Korea & 0.195 & 0.070 & 0.083 & 0.047 & 0.104 & 0.053 & 0.000 & 0.029 \\
Turkey & 0.012 & 0.017 & 0.068 & 0.069 & 0.015 & 0.078 & 0.011 & 0.000 \\
\hline
\end{tabular}

Source: authors' calculation

\subsection{Unit Root Test}

In the next step, we generalized the stationery of internal and external variables (weighted average of variables in other countries in relation (11) and using the matrix of computational coefficients in Table (1)) of the model using the Dickey-Fuller unit root test. The results of the unit root test can be seen in Tables (2) and (3):

Table 2

Augmented Dickey-Fuller Unit Root Test for domestic variables

\begin{tabular}{|c|c|c|c|c|c|c|c|c|c|}
\hline & Critical Value & China & India & Iran & Russian & United States & EURO & Korea & Turkey \\
\hline \multicolumn{10}{|l|}{$y_{t}$} \\
\hline With Trend & -3.45 & -1.57 & -1.84 & -0.04 & -1.27 & -2.35 & -2.29 & -2.41 & -3.75 \\
\hline No Trend & -2.89 & -0.93 & 0.52 & -1.73 & -1.18 & -2.28 & -2.02 & -1.08 & -1.14 \\
\hline First Difference & -2.89 & -1.76 & -5.46 & -6.60 & -4.57 & -3.75 & -3.72 & -5.56 & .5 .00 \\
\hline \multicolumn{10}{|l|}{$p_{t}$} \\
\hline With Trend & -3.45 & -4.52 & -5.13 & -3.41 & -5.61 & -6.01 & -3.90 & -5.51 & -1.10 \\
\hline No Trend & -2.89 & -3.98 & -5.03 & -3.37 & -5.02 & -5.83 & -3.66 & -4.96 & -1.54 \\
\hline First Difference & -2.89 & -7.02 & -7.89 & -7.67 & -7.10 & -7.08 & -10.51 & -10.05 & -6.73 \\
\hline \multicolumn{10}{|l|}{$r e_{t}$} \\
\hline With Trend & -3.45 & -2.43 & -2.06 & -2.03 & -1.52 & & -1.92 & -3.09 & -1.41 \\
\hline No Trend & -2.89 & -0.52 & -0.18 & -2.02 & -1.12 & & -1.26 & -1.28 & -1.39 \\
\hline First Difference & -2.89 & -2.85 & -5.80 & -6.09 & -6.01 & & -3.10 & -6.87 & -6.40 \\
\hline \multicolumn{10}{|l|}{$i n_{t}$} \\
\hline With Trend & -3.45 & -2.90 & -3.40 & -2.01 & -4.29 & -4.12 & -3.58 & -1.91 & -1.66 \\
\hline No Trend & -2.89 & -3.07 & -2.95 & -1.16 & -3.47 & -2.07 & -1.77 & -1.76 & -1.24 \\
\hline First Difference & -2.89 & -6.41 & -5.33 & -7.04 & -6.02 & -3.76 & -4.55 & -3.91 & -7.23 \\
\hline
\end{tabular}


Table 3

Augmented Dickey-Fuller Unit Root Test for foreign variables

\begin{tabular}{|c|c|c|c|c|c|c|c|c|c|}
\hline Foreign Variables & Critical Value & China & India & Iran & Russian & United States & EURO & Korea & Turkey \\
\hline \multicolumn{10}{|c|}{$y_{t}^{*}$} \\
\hline With Trend & -3.45 & -1.27 & -1.00 & -0.68 & -1.73 & -0.67 & -1.11 & -0.53 & -1.34 \\
\hline No Trend & -2.89 & -1.67 & -1.50 & -1.61 & -2.01 & -1.14 & -1.64 & -1.59 & -1.68 \\
\hline First Difference & -2.89 & -3.87 & -4.53 & -3.09 & -4.35 & -2.99 & -3.97 & -2.70 & -4.08 \\
\hline \multicolumn{10}{|l|}{$p_{t}^{*}$} \\
\hline With Trend & -3.45 & -6.21 & $\begin{array}{l}-5.38 \\
\end{array}$ & -3.53 & -5.05 & -5.43 & -5.30 & -5.63 & -5.69 \\
\hline No Trend & -2.89 & -4.68 & -5.10 & -2.36 & -2.14 & -5.40 & -2.73 & -5.64 & -5.04 \\
\hline First Difference & -2.89 & -7.34 & -7.00 & -10.29 & -6.90 & -8.70 & -6.88 & -6.62 & -6.85 \\
\hline \multicolumn{10}{|l|}{$r e_{t}^{*}$} \\
\hline With Trend & -3.45 & -1.94 & -1.89 & -1.85 & -1.49 & -2.11 & -1.44 & -1.87 & -1.55 \\
\hline No Trend & -2.89 & -0.88 & -0.70 & -0.74 & -0.79 & -0.70 & -0.66 & -0.49 & -0.94 \\
\hline First Difference & -2.89 & -5.97 & -5.59 & -2.73 & -2.79 & -5.18 & -3.71 & -4.54 & -5.56 \\
\hline \multicolumn{10}{|l|}{$i n_{t}^{*}$} \\
\hline With Trend & -3.45 & -2.33 & -2.45 & -2.82 & -3.09 & -3.04 & -2.95 & -2.99 & -4.06 \\
\hline No Trend & -2.89 & -2.09 & -2.39 & -2.01 & -1.26 & -1.98 & -2.49 & -2.91 & -3.39 \\
\hline First Difference & -2.89 & -4.90 & -5.05 & -5.78 & -5.65 & -5.36 & -6.38 & -5.51 & -6.10 \\
\hline
\end{tabular}

The results of the unit root test indicate that the model variables are nonstationary and are stationary once the differentiation is done. This allows us to distinguish between short-term and long-term relationships between variables, and to estimate the long-run relationship between variables. cointegration vectors between the variables. Accordingly, instead of the VAR model, we constructed a vector error correction model (VECM), VECMX ${ }^{*}$, with cointegration vectors in equation (13).

\subsection{Modeling the Error Correction Model VECM ${ }^{*}$}

To estimate the model VECMX $X^{*}$, first the optimal order of the $\operatorname{VARX}^{*}\left(p_{i}, q_{i}\right)$ model of each country is selected in Table (4). $\mathrm{p}_{i}$, the lag order of the internal variables, and $\mathrm{q}_{i}$, the lag order of interrupt of external variables (stars) are selected according to the Akaike Information Criterion (AIC). The order of cointegrating space for each country is calculated using the Johansen's maximum eigenvalue statistic discussed in the study of Pesaran et al. (2000) for models with estimators I (1) and weakly exogenous while the fixed values are finite. 
Table 4

Optimal Order of the VARX ${ }^{*}$ and Cointegration Relationships

\begin{tabular}{lccc}
\hline & $\boldsymbol{q}_{\boldsymbol{i}}$ & $\boldsymbol{p}_{\boldsymbol{i}}$ & $\boldsymbol{r}_{\boldsymbol{i}}$ \\
\hline China & 2 & 1 & 2 \\
India & 3 & 1 & 2 \\
Iran & 2 & 1 & 1 \\
Russian & 3 & 3 & 1 \\
United States & 3 & 1 & 3 \\
EURO & 1 & 3 & 1 \\
Korea & 3 & 2 & 3 \\
Turkey & 3 & 3 & 2 \\
\hline
\end{tabular}

Note: $r_{i}$ denotes the cointegration rank in the model of country $i$; $p_{i}$ denotes the number of lags for the endogenous variables in the model of country $i$; $q_{i}$ denotes the number of lags for the (assumed) weakly exogenous (foreign) variables.

\subsection{Testing Weak Exogeneity}

As stated earlier, the main assumption in our estimation strategy is the weak exogenous $x_{i t}^{*}$ with respect to the long-run parameters of the conditional model defined in Equation (13). We now present a formal test to test this hypothesis for country-specific external variables (star variables).

Weak exogeneity is discussed in the study by Johansen (1992) and Harbo et al. (1998). This includes a test of the combined significance of the estimated error correction expressions in the auxiliary equations for specific external variables $x_{i t}^{*}$. Specifically, for each $i$ th element of $x_{i t}^{*}$ the following regression is performed:

$\triangle x_{i t, l}^{*}=\mu_{i l}+\sum_{j=1}^{r_{i}} \gamma_{i j, l} E C M_{i, t-1}^{j}+\sum_{k=1}^{s_{i}} \varphi_{i k, l} \Delta x_{i, t-k}+\sum_{m=1}^{n_{i}} \vartheta_{i m, l} \Delta$

$\tilde{x}_{i, t-m}^{*}+\varepsilon_{i t, l}$

where the $\operatorname{ECM}_{i, t-1}^{j}$ for $j=1,2, \ldots, r_{i}$, is the estimated error correction terms obtained for the $i$ th country model using the cointegration relationships $r_{i}$ and $\Delta \tilde{X}_{i t}^{*}=\left(\Delta X_{i t}^{\prime *}, \Delta\left(e_{i t}^{*}-p_{i t}^{*}\right), \Delta p_{t}^{o}\right)^{\prime}$. The test for weak exogeneity is an F-test of the joint hypothesis that $\gamma_{i j, l}=0, j=1,2, \ldots, r_{i}$ in Equation 19. As seen in Table 5, we cannot reject a weak exogeneity assumption at a significance level of 5 percent for most of the variables examined. Hence, a weak exogeneity assumption for India, China, and United States' GDP, Turkey, and Russian Federation's inflation, and China and United States' interest rates are rejected, suggesting that these variables are not significantly influenced by foreign variables. 
Table 5

Test Statistic for Weak Exogeneity

\begin{tabular}{lrrrrrr}
\hline Country & $\boldsymbol{i} \boldsymbol{n}_{\boldsymbol{t}}^{*}$ & $\boldsymbol{r} \boldsymbol{e}_{\boldsymbol{t}}^{*}$ & $\boldsymbol{p}_{\boldsymbol{t}}^{*}$ & $\boldsymbol{y}_{\boldsymbol{t}}^{*}$ & Fcrit_0.05 & F-test \\
\hline China & 1.29 & & 4.41 & 5.48 & 3.14 & $\mathrm{~F}(2,66)$ \\
India & 1.08 & & 0.71 & 5.62 & 3.14 & $\mathrm{~F}(2,66)$ \\
Iran & 0.61 & & 15.77 & 0.16 & 3.98 & $\mathrm{~F}(1,67)$ \\
Russian & 6.16 & & 1.69 & 5.59 & 3.98 & $\mathrm{~F}(1,67)$ \\
United States & & 4.34 & 3.65 & 2.25 & 2.74 & $\mathrm{~F}(3,66)$ \\
EURO & 2.84 & & 1.96 & 0.63 & 3.98 & $\mathrm{~F}(1,67)$ \\
Korea & 0.96 & & 0.35 & 1.63 & 2.77 & $\mathrm{~F}(3,57)$ \\
Turkey & 5.98 & & 1.16 & 0.23 & 3.16 & $\mathrm{~F}(2,58)$ \\
\hline
\end{tabular}

\subsection{Simultaneous Effects between Domestic and Foreign Variables}

Table (6) shows the simultaneous effects of external variables on their internal counterparts for t-ratios, calculated using the White's heteroscedasticityconsistent variance estimator. These values can be interpreted as effective elasticities between internal and external variables. Most of these tensions are significant as expected. Provide information on international links between internal and external variables. By focusing on the Iranian economy in table 5 , one can see that a 1 percent change in the foreign real production in any given quarter leads to a 0.39 percent increase in real production in Iran's economy within the same quarter. This increase is not significant.

Table 6

Elasticities of the Effect between Domestic and Foreign Variables

\begin{tabular}{llccc}
\hline & & $\boldsymbol{y}_{\boldsymbol{t}}$ & $\boldsymbol{p}_{\boldsymbol{t}}$ & $\boldsymbol{i n}_{\boldsymbol{t}}$ \\
\hline China & Coefficient & 0.69 & 0.24 & 0.37 \\
& t-ratio & 3.44 & 1.65 & 4.37 \\
\hline India & Coefficient & 0.54 & 0.70 & 0.41 \\
& t-ratio & 1.51 & 1.64 & 1.71 \\
\hline Iran & Coefficient & 0.40 & 0.42 & 0.03 \\
& t-ratio & 0.93 & 0.74 & 0.17 \\
\hline Russia & Coefficient & 0.53 & 0.13 & 3.00 \\
& t-ratio & 1.97 & 0.17 & 2.00 \\
\hline United States & Coefficient & 0.27 & 0.58 & \\
& t-ratio & 2.57 & 3.36 & \\
\hline EURO & Coefficient & 0.31 & 0.12 & 0.09 \\
& t-ratio & 4.67 & 3.01 & 3.24 \\
\hline South Korea & Coefficient & 0.24 & 0.57 & -0.71 \\
& t-ratio & 1.22 & 4.83 & -1.88 \\
\hline Turkey & Coefficient & 0.43 & 0.81 & 2.05 \\
& t-ratio & 0.34 & 1.55 & 2.69 \\
\hline
\end{tabular}




\subsection{The Impulse Response of One Positive Shock to Interest Rate}

In this section, to examine the symmetric or asymmetric behavior of countries' external shocks, using the Impulse Response Function, we empirically examine the effects of an increase in interest rates (considered as contractionary monetary policy) of Iran's trading partners on Iran's macroeconomic variables.

Figure 1 shows the asymmetric response of a one standard error positive shock to interest rates of other countries on Iran's interest rate. According to the figure, the impulse response of Iran's interest rate to an increase in interest rates is significant. Also, the impulse response of the positive shock to China, the European Union, South Korea, United States, and Turkey interest rate on Iran's interest rate is positive, however, the confidence intervals indicate that the positive response is more significant for China, Korea, Turkey, and the EU than for other countries. Also, the impulse response of the positive shock of the interest rates in India and Russia is negative and completely meaningless on Iran's interest rate.

Figure 2 shows the impulse response of one standard error positive shock to interest rates of different countries on Iran's inflation. The results indicate that domestic interest rates increase has a positive effect on Iran's inflation. These effects are in contrast with theoretical foundations and have been titled Price Puzzle in various international empirical studies. The results illustrate a form of Price Puzzle on how monetary policy shocks affect inflation (Castelnuovo, 2012).

Using a vector autoregressive (VAR) approach, Sims (1992) found that an increase in the interest rate leads to an increase in inflation in several industrialized economies. This observation was against the general prediction of economists and economic textbooks and subsequently labeled as "price puzzle". Since the work of Sims (1992), several studies have attempted to explain why the price puzzle occurs. The current literature contains many papers that still find the puzzle in empirical vector autoregression (VARs) models with some proposing solutions to solve the Price Puzzle (for a discussion, see Castelnuovo, 2012).

Some articles stress the role of omitted variables from the model as a reason for the price puzzle. Sims (1992) proposes to include a measure of commodity price increases in the VAR as a proxy for unobserved inflation expectations. Giordani (2004) shows that once the output is replaced by the output gap in the empirical model, the price puzzle vanishes at least in the quarterly data. 


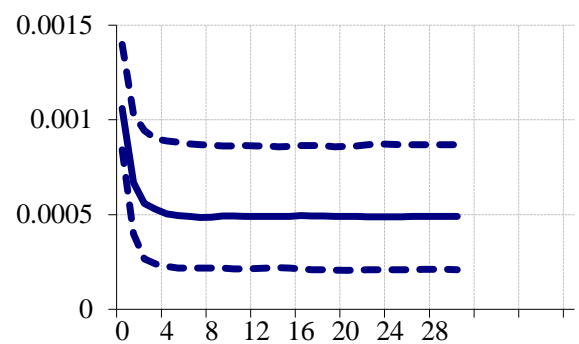

a) Iran

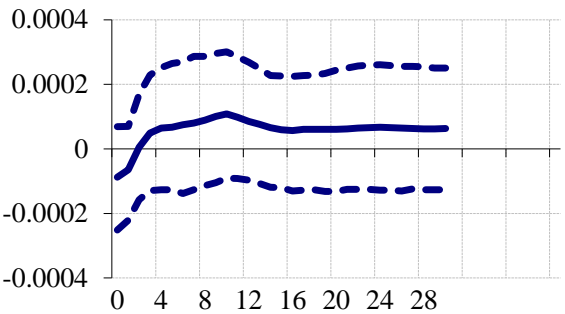

c) The EU

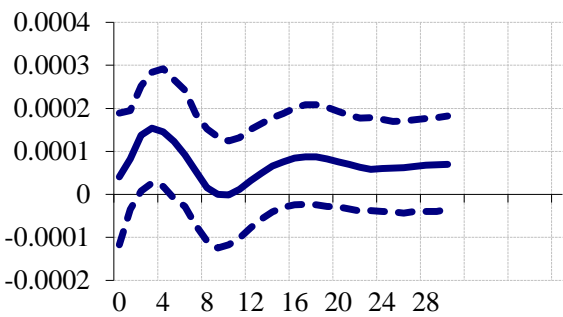

e) Korea

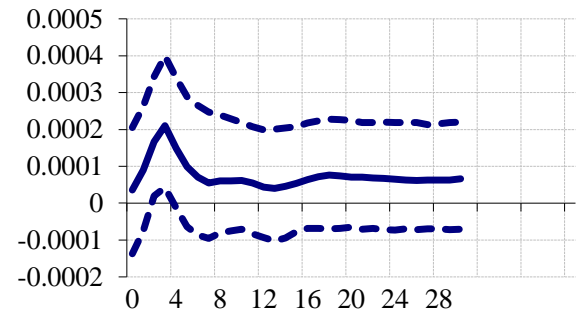

g) Turkey

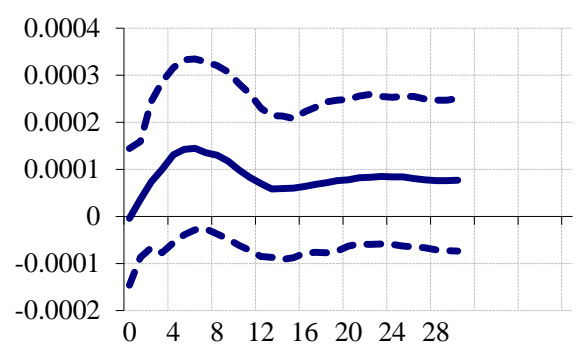

b) China

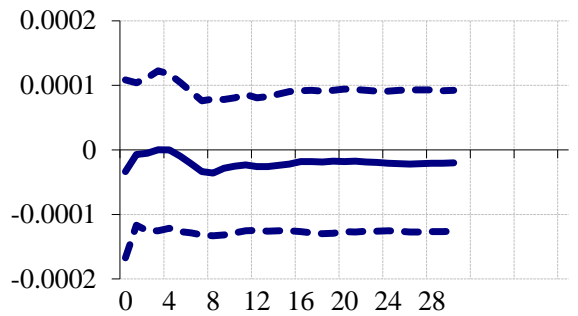

d) India

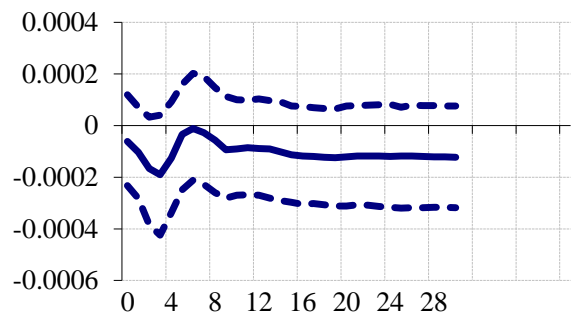

f) Russia

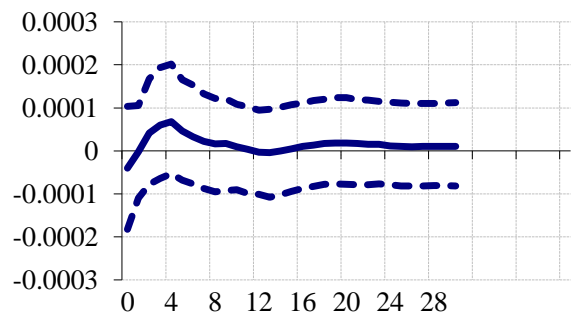

h) The United States

Figure 1. The Impulse Response of One Positive Shock to the Interest Rate of Each Country Iran's Interest Rate. 
Kapinos (2011) showed that ignoring the effect of anticipated shocks to inflation and the forward-looking behavior of the central bank can give rise to the price puzzle. Bernanke et al. (2005) make use of additional information by extracting principal components from many time series. Likewise, Auray and Feve (2008) pointed out that price puzzle occurs when, despite price flexibility, monetary authorities choose a money supply rule over the interest rate rule. However, some articles denoted that Price Puzzle is historically limited to periods of passive monetary policy or that it emerges when the data mix different monetary regimes (Elbourne \& de Haan, 2006; Borys et al., 2009). Galles and Portier (2005) found that the price puzzle was not very visible in the quarterly data. Castelnuovo and Surico (2010) found evidence of the price puzzle in US data for 1966-1979 but not for 1979-2002. Benati (2008) presents similar evidence for the United Kingdom. Irvendi and Guloglu (2010) found that contractionary monetary policy shocks do not give rise to price puzzle in five inflation-targeting countries (i.e., Australia, New Zealand, Canada, Sweden, and the UK).

Another possibility mentioned for the price puzzle is the existence of a cost channel of monetary policy transmission. This channel is realized when an increase in the nominal interest rate increases the cost of production. Barth and Ramey (2002) emphasize the supply-side effects and present evidence for the so-called cost channel detecting a strong cost channel in the pre-1979 industry-level data from the US. However, Rabanal (2003) failed to detect a strong cost channel in the post-1984 US data. For the United States, Christiano et al. (2005) build a DSGE model incorporating the cost channel, but only find a minor role for it in explaining the price puzzle. Gaiotti and Secchi (2006) argued that manufacturing sector firms respond to contractionary monetary policy shocks with high prices. Using quarterly data, Ravenna and Walsh (2006) confirmed the presence of a cost channel in the US economy. Rabanal (2007) suggests that the demand-side effects of monetary policy dominate the supply-side effects, thus leaving the cost channel relatively unimportant. Henzel et al. (2009) come to similar conclusions for the European Union. Tillman (2008) supported the presence of a strong cost channel in the US economy. Also, some articles argue implausible identification of monetary policy shocks as a reason for Price Puzzle (Kim, 1999; and Kim \& Roubini, 2000; Canova \& Nicolo, 2002; Uhlig, 2005; Fry \& Pagan, 2011). The recent work of Ali and Anwar (2016) points to yet another form of model misspecification. They showed that despite the presence of a cost channel, a sufficiently high level of exchange rate pass-through can avert the possibility of a price puzzle. 


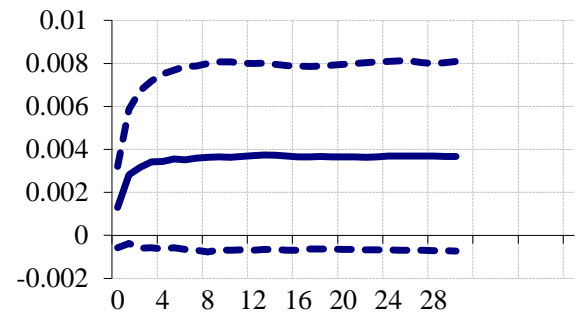

a) Iran

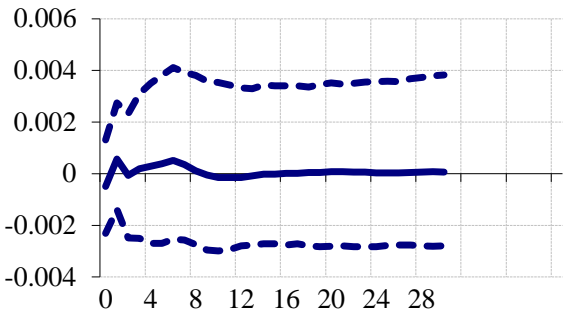

c) The EU

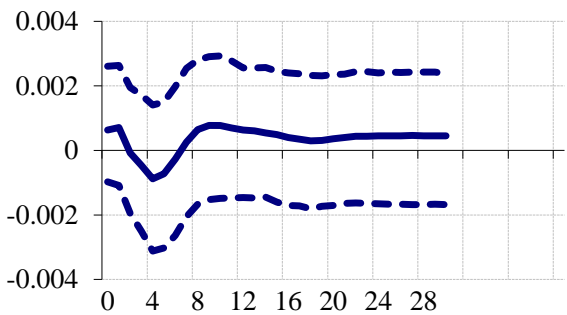

e) Korea

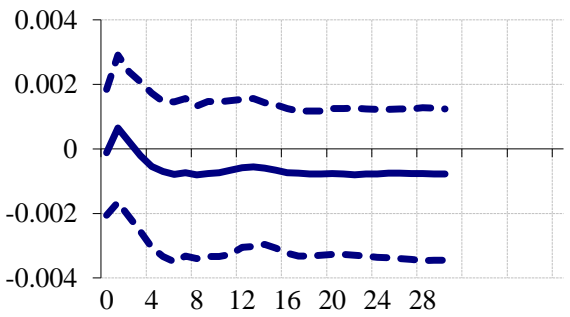

g) Turkey

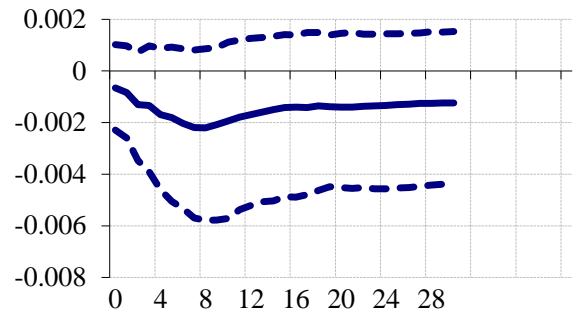

b) China

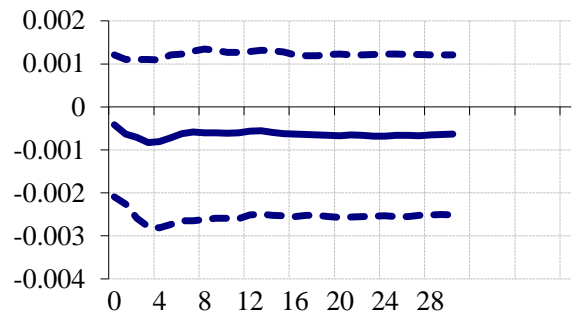

d) India

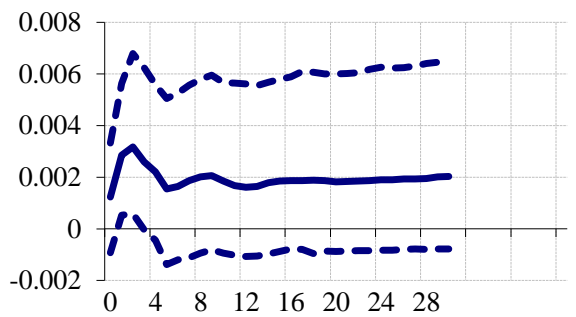

f) Russia

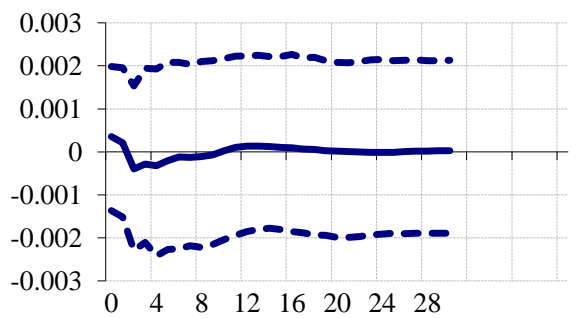

h) The United States

Figure 2. The Impulse Response of One Positive Shock to the Interest Rate of Each Country on Iran's Inflation. 
The existing studies on price puzzle are based on models that assume that all shocks, including the monetary shocks, are unanticipated (or surprise shocks), but a few ones have concentrated on anticipated shocks. Kapinos (2011) demonstrated the emergency of the price puzzle due to the presence of anticipated cost-push shocks and forward-looking conduct of monetary policy. Best and Kapinos (2017) introduce anticipated components to the model's stochastic shocks to show the emergence of the price puzzle in response to a variety of news shocks while assuming a standard Taylor rule. Ali and Anwar (2018) show that even if the exchange rate pass-through was not present, factors such as a sufficiently high degree of openness of the economy, the cost of price adjustment, a high interest rate elasticity of aggregate demand, or an anticipated monetary shock can solve the price puzzle.

Also, Iran's inflation response to one standard error positive shock to interest rates of China, India, and Turkey is negative, while only the effect of China's interest rate is significant and negative. Also, the response of Iran's inflation to the contractionary monetary policy of Russia is positive.

Figure 3 illustrates the impulse response of one standard error positive shock to interest rates of different countries on Iran's real GDP. According to the results, the effects of the positive shocks of domestic interest rate on real GDP in Iran is negative. Also, the effects of the positive shocks in other countries interest rates on Iran's real GDP is positive for China, India, Korea, Russia and negative for Turkey and the EU, so that the effects are not significant for any country. The results indicate significant independence of Iran's real GDP to the monetary policy shocks of other trading partners of Iran.

Figure 4 illuminates the effects of a one standard error positive shock to interest rates of different countries on Iran's real exchange rate. Based on the results of the impulse response, Iran's real exchange rate response to the positive shock of domestic interest rates of Iran is negative and significant. Besides, the response of Iran's real exchange rate to positive shocks in Korea, Russia, Turkey, the European Union, and the United States is positive, however, the positive effect for the EU is at a significant level, also for Turkey until the end of the 6th period, there are positive and significant effects, but from the 6th period onwards, the positive effects move toward zero and a meaningless level. The positive effects are not significant for other countries. Also, for other countries, the significant effects of the real exchange rate response of Iran to positive shocks at the interest rate in some periods are positive and in some periods negative, but in the whole period is at a meaningless level. 


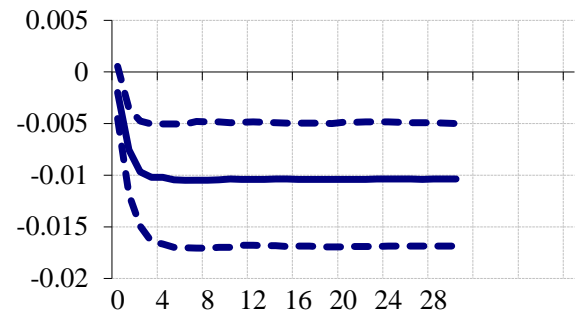

a) Iran

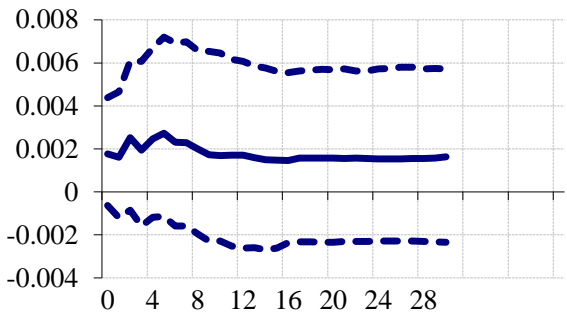

c) The EU

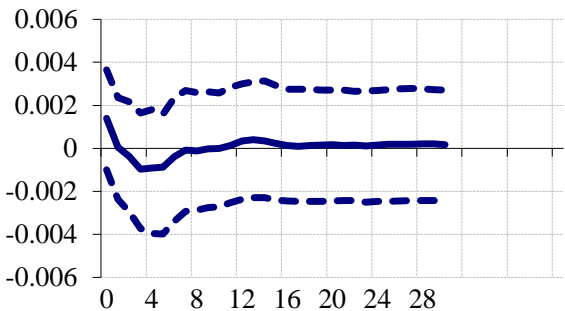

e) Korea

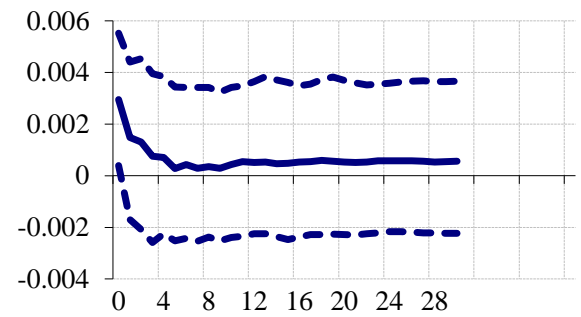

g) Turkey

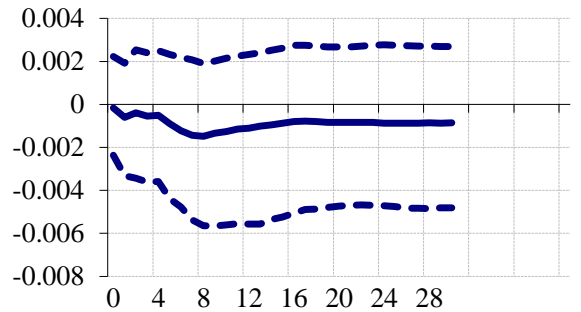

b) China

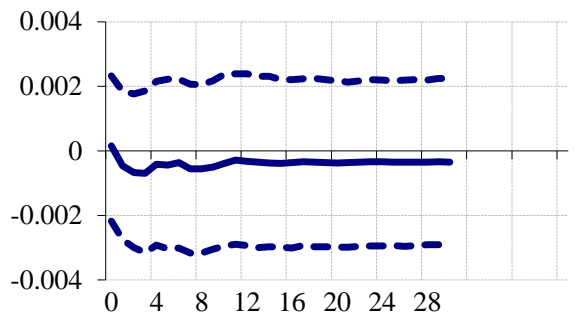

d) China

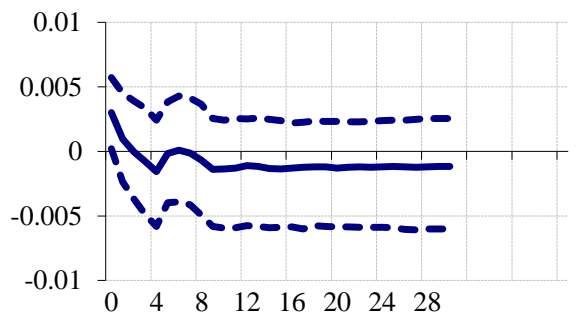

f) Russia

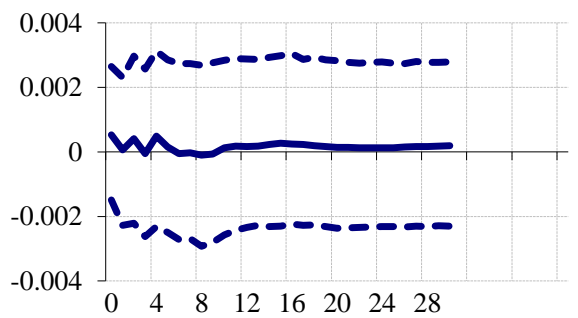

h) The United States

Figure 3. The Impulse Response of One Positive Shock to the Interest Rate of Each Country on Iran's Real GDP. 


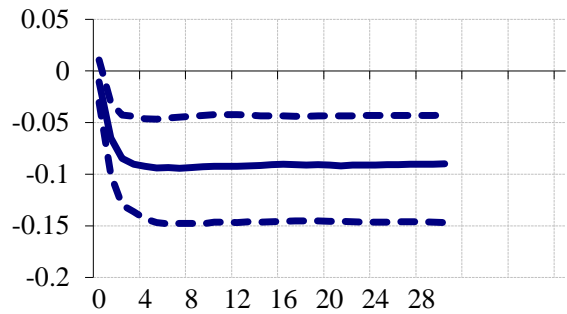

a) Iran

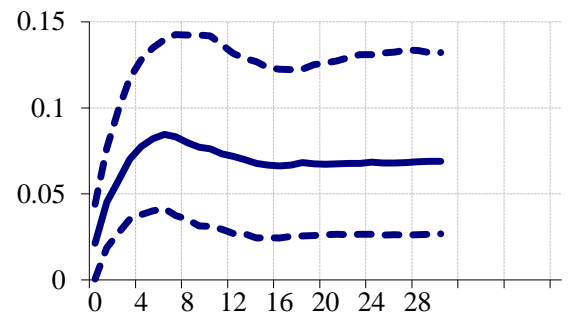

c) The EU

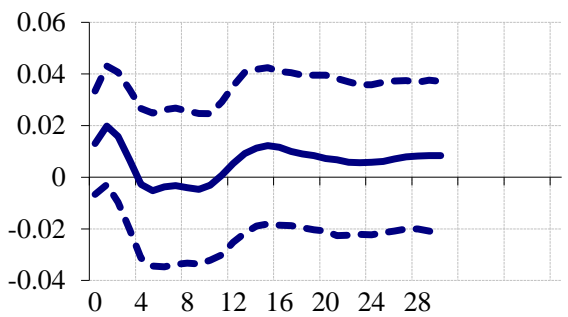

e) Korea

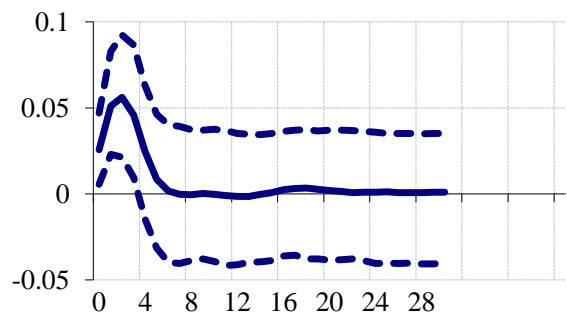

g) Turkey

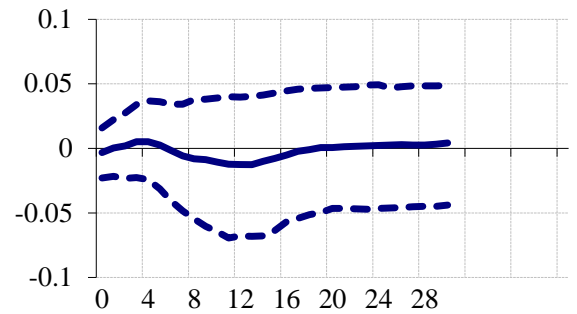

b) China

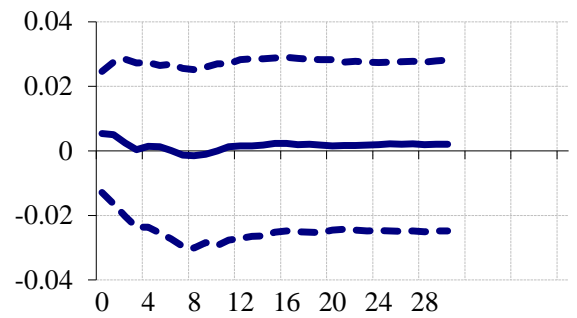

d) India

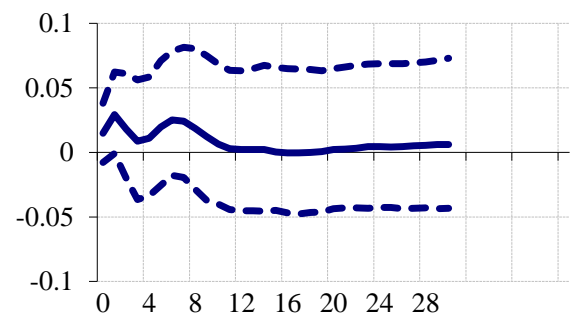

f) Russia

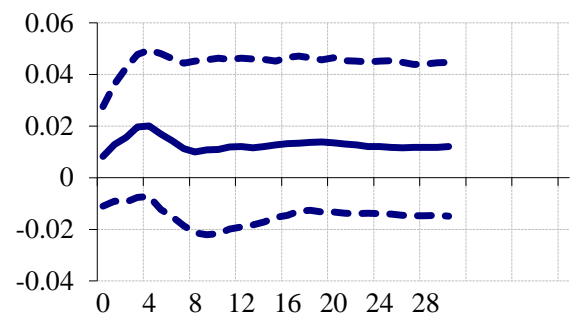

h) The United States

Figure 4. The Impulse Response of One Positive Shock to the Interest Rate of Each Country on Iran's Real Exchange Rate. 


\section{Conclusion}

One of the most striking features of the business cycles across countries is the patterns of co-movement of output, inflation, interest rates, and real equity prices. Using quarterly data over the 1996Q1-2015Q4 period and a global vector auto-regression model (GVAR) for Iran and its largest trading partners including China, India, Russia, South Korea, Turkey, the European Union, and the United States, this paper empirically examines the effects of domestic and foreign monetary policies on Iran's macroeconomic variables (including real production, inflation, short-term interest rate, and real exchange rate).

The results of investigating the simultaneous effects of foreign variables on their domestic counterparts illustrate that the effects of China are higher than other countries, reflecting the stronger dependence of this country on foreign variables. The results indicate that, except for the United States, Korea, and the European Union, the changes in foreign prices have a minor effect on Iran's domestic prices than in other countries. The other significant feature of these results is strong links among the interest rates in the countries under the study. This indicates a strong connection to the monetary policy of countries, especially in China, Russia, the European Union, Korea, and Turkey, while there is no significant link to the Iranian economy. These results provide information on the weak international links between domestic and foreign variables for Iran. These results indicate the closed economic structure of Iran so that global economic crises that lead to a recession in other countries had the least impact on the Iranian economy.

The results of domestic monetary policies on Iran's macroeconomic variables illustrate a form of Price Puzzle on how monetary policy shocks affect inflation in Iran. Also according to the results, the effect of a positive shock to the domestic interest rate on real GDP in Iran is negative. Based on the results, Iran's real exchange rate response to the positive shock of domestic interest rates and the contractionary monetary policy of Iran is negative and significant.

The results of foreign monetary policies on Iran's macroeconomic variables show that the positive shock to China, the European Union, Korea, United States, and Turkey interest rate on Iran's interest rate is positive and this positive response is more significant for China, Korea, Turkey, and the EU than for other countries. Also, only the effects of a positive shock to China's interest rate are significant and negative on Iran's inflation. Furthermore, the results indicate significant independence of Iran's real GDP from the monetary policy shocks of other trading partners of Iran. These results are in line with the result of investigating the simultaneous effects of foreign variables on their 
domestic counterparts. Besides, the response of Iran's real exchange rate to positive shocks in the EU is at a positive and significant level, also for Turkey until the end of the 6th period, there are positive and significant effects, but from the 6th period onwards, the positive effects move toward zero and a meaningless level.

A contractionary foreign monetary policy shock decreases foreign demand for domestic goods, which decreases domestic exports and domestic output via the open-economy IS curve (income absorption effect or demand channel). On the other hand, the domestic exchange rate depreciates after the contractionary foreign monetary. In countries with a fixed exchange rate regime, the trade channel suggests that domestic output should move in the same direction as foreign output via increased foreign demand. In countries with flexible exchange rates, however, the exchange rate adjustment counteracts the demand channel and the direction of spillovers via trade is a priori ambiguous. Considering that Iran's exchange rate is constant, the monetary policy of other countries has led to an increase in the Iranian exchange rate, according to which the results are in line with theoretical foundations.

The effects of China's contractionary monetary policy on inflation in Iran can also be interpreted in the form of a demand channel since declining demand for domestic goods and a reduction in output can reduce demand pressure and lead to a reduction in domestic inflation. However, another channel that could be considered is the fall in the prices of imported intermediate goods and capital (accounting for almost 70 percent of Iran's imports) from China and a decline in domestic production costs, which can be interpreted as a cost pressure channel of China's contractionary monetary policy on Iran's inflation.

\section{References}

Agbeyegbe, T. D. (2008). On the Feasibility of a Monetary Union in the Southern Africa Development Community. International Journal of Finance \& Economics, 13(2), 150-157.

Aizenman, J., Chinn, M. D., \& Ito, H. (2016). Monetary Policy Spillovers and the Trilemma in the New Normal: Periphery Country Sensitivity to Core Country Conditions. Journal of International Money and Finance, 68, 298-330.

Ali, S., Anwar, S., (2016). Can exchange rate pass-through explain the price puzzle? Economics Letters, 145, 56-59.

Ali, S.Z., Anwar, S., (2018). Price puzzle in a small open New Keynesian model. The

Quarterly Review of Economics and Finance, 69, 29-42 
Auray, S., and Feve. P., (2008). On Sunspots, Habits, and Monetary Facts. Macroeconomic Dynamics, 12, 72-96.

Barigozzi, M., Conti, A. M., \& Luciani, M. (2014). Do Euro Area Countries Respond Asymmetrically to the Common Monetary Policy? Oxford Bulletin of Economics and Statistics, 76(5), 693-714.

Barth, M. J. and V. A. Ramey (2002): The Cost Channel of Monetary Transmission, in NBER Macroeconomics Annual 2001, Volume 16, National Bureau of Economic Research, Inc, NBER Chapters, 199-256.

Belke, A. H. \& Osowski, T. (2016). Measuring Fiscal Spillovers in Emu and Beyond: A Global VAR Approach. CEPS Working Document No. 428, Brussels: Centre for European Policy Studies.

Benkovskis, K., Bessonovs, A., Feldkircher, M., \& W"orz, J. (2011). The Transmission of Euro Area Monetary Shocks to the Czech Republic, Poland and Hungary: Evidence from A FAVAR Model. Focus on the European Economic Integration, 8-36.

Bernanke, B. S., \& Gertler, M. (1995). Inside The Black Box: The Credit Channel of Monetary Policy Transmission. Journal of Economic Perspectives, 9(4), 27-48.

Bernanke, B., Boivin, J., \& Eliasz, P. (2005). Measuring Monetary Policy: A Factor Augmented Vector Autoregressive (FAVAR) Approach. Quarterly Journal of Economics, 120, 387-422.

Best, G., and Kapinos, P., (2017). News, Real-time Forecasts, and the Price Puzzle. Available at SSRN: https://ssrn.com/abstract=2886190 or http://dx.doi.org/10.2139/ssrn.2886190.

Bluwstein, K., \& Canova, F. (2015). Beggar-Thy-Neighbor? The International Effects of ECB Unconventional Monetary Policy Measures. CEPR Discussion Papers.

Boivin, J., Giannoni, M. P., \& Mojon, B. (2008). How Has the Euro Changed the Monetary Transmission? NBER Working Paper No. 14190.

Borys, M., Horvath, R., and Franta, M., (2009). The effects of monetary policy in the Czech Republic: an empirical study. Empirica, 36(4), 419-443.

Bruno, V. and H. S. Shin (2015a). Capital Flows and the Risk-taking Channel of Monetary Policy. Journal of Monetary Economics 71, 119-132.

Bruno, V. and H. S. Shin (2015b). Cross-border Banking and Global Liquidity. The Review of Economic Studies, 82 (2), 535-564

Canova, F. (2005). The Transmission of US Shocks to Latin America. Journal of Applied Econometrics, 20(2), 229-251.

Canova, F., \& Marrinan, J. (1998). Sources and Propagation of International Cycles: Common Shocks or Transmission? Journal of International Economics, 42(1), 133-167.

Canova, F., and de Nicoló, G., (2002). Monetary disturbances matter for business fluctuations in the g-7. J. Monet. Econ, 49, 1131-1159.

Castelnuovo, E. and P. Surico (2010): Monetary Policy, Inflation Expectations and The Price Puzzle. Economic Journal, 120, 1262-1283. 
Castelnuovo, E., (2012). Testing the structural interpretation of the price puzzle with a cost-channel model. Oxford Bulletin of Economics and Statistics, 74, 425-452.

Cetorelli, N., \& Goldberg, L. S. (2012). Banking Globalization and Monetary Transmission. The Journal of Finance, 67(5), 1811-1843.

Christiano, L., Eichenbaum, M., and Evans, C., (2005). Nominal Rigidities and the Dynamic Effect of a Shock to Monetary Policy. Journal of Economic Dynamics, 8(2), 262-302.

Cwik, T., Müller, G. J., \& Wolters, M. H. (2011). Does Trade Integration Alter Monetary Policy Transmission? Journal of Economic Dynamics and Control, 35(4), 545-564.

Dedola, L., Rivolta, G., \& Stracca, L. (2016). If the Fed Sneezes, Who Gets a Cold? NBER Chapters, in: NBER International Seminar on Macroeconomics 2016 National Bureau of Economic Research, Inc.

Devereux, M. B., \& Yetman, J. (2010). Leverage Constraints and the International Transmission of Shocks. Journal of Money, Credit and Banking, 42(s1), 71-105.

Dornbusch, R. (1980). Open Economy Macroeconomics. Basic Books New York.

Dragomirescu-Gaina, C., \& Philippas, D. (2015). Strategic Interactions of Fiscal Policies in Europe: A Global VAR Perspective. Journal of International Money and Finance, 59, 49-76.

Eickmeier, S., \& Breitung, J. (2006). How Synchronized Are New EU Member States with the Euro Area? Evidence from a Structural Factor Model. Journal of Comparative Economics, 34(3), 538-563.

Elbourne, A. and de Haan, J., (2006). Financial structure and monetary policy transmission in transition countries. Journal of Comparative Economics, 34(1), 123.

Feldkircher, M. (2014). A Global Macro Model for Emerging Europe. Journal of Comparative Economics, 43(3), 706-726.

Feldkircher, M., \& Huber, F. (2016). The International Transmission of US Shocks Evidence from Bayesian Global Vector Autoregressions. European Economic Review, 81, 167-188.

Forni, M., \& Reichlin, L. (1998). Let's Get Real: A Factor Analytical Approach to Disaggregated Business Cycle Dynamics. Review of Economic Studies, 65, 453473.

Forni, M., Lippi, M., \& Reichlin, L. (2003). Opening the Black Box: Structural Factor Models versus Structural VARs, CEPR Discussion. Paper No. 4133.

Fry, R., and Pagan, A., (2011). Sign restrictions in structural vector autoregressions: A critical review. Journal of Economic Literature, 49 (4), 938-960.

Gaiotti, E., and Secchi, A., (2006). Is There a Cost Channel of Monetary Policy Transmission? An Investigation into the Pricing Behavior of 2,000 Firms. Journal of Money, Credit and Banking, 38, 2013-2037

Gali, J., \& Monacelli, T. (2005). Monetary Policy and Exchange Rate Volatility in a Small Open Economy. The Review of Economic Studies, 72(3), 707-734. 
Galles, C., and Portier, F., (2005). Does the Length of the Period Really Matter for the Identification and the Modelling of Monetary Policy Shocks? Mimeo.

Giordani, P. (2004): An alternative explanation of the price puzzle, Journal of Monetary Economics, 51, 1271-1296.

Granger, C. W. J., \& Lin, J. L. (1995). Causality in the Long Run, Econometric Theory, 11, 530-536.

Gregory, A. W., Head, A. C., \& Raynauld, J. (1997). Measuring World Business Cycles. International Economic Review, 38, 677-701.

Gurara, D. Z., \& Mthuli, N. (2013). Global Economic Spillovers to Africa: A. GVAR Approach, Working Paper Series No. 183, Tunis: African Development Bank.

Hájek, J., \& Horváth, R. (2015). The Spillover Effect of Euro Area on Central and Southeastern European Economies: A Global VAR Approach. Open Economies Review, 1-27.

Harbo, I., Johansen, S., Nielsen, B., \& Rahbek, A. (1998). Asymptotic Inference on Cointegrating Rank in Partial Systems. Journal of Business \& Economic Statistics, 16, 388-399.

Henzel, S., Hulsewig, O., Mayer, E., and Wollmershäuser, T., (2009). The price puzzle revisited: Can the cost channel explain a rise in inflation after a monetary policy shock? Journal of Macroeconomics, 31, 268-289.

Horvath, R., \& Voslarova, K. (2016). International Spillovers of ECB's Unconventional Monetary Policy: The Effect on Central Europe. Applied Economics, 1-13.

Irvendi, M., Guloglu, B., (2010). Monetary shocks, exchange rates and trade balances: evidence from inflation targeting countries. Economic Modelling, 27, 1144-1155.

Jannsen, N., \& Klein, M. (2011). The International Transmission of Euro Area Monetary Policy Shocks. Kiel Working Papers 1718.

Jiménez-Rodriguez, R., Morales-Zumaquero, A., \& Égert, B. (2010). The Effect of Foreign Shocks in Central and Eastern Europe. Journal of Policy Modeling, 32(4), 461-477.

Johansen, S. (1992). Cointegration in Partial Systems and the Efficiency of SingleEquation Analysis. Journal of Econometrics, 52, 231-254.

Kapinos, P., (2011). Forward-Looking Monetary Policy and Anticipated Shocks to Inflation. Journal of Macroeconomics, 33, 620-633.

Khezri, M., Zulkhibri, M., \& Ghazal, R. (2019). Regional Integration, Monetary Cooperation: Evidence from Global VAR Models for the Member States of the Shanghai Cooperation Organization. Global Journal of Emerging Market Economies, 11(1-2), 65-79.

Kim, S. (2001). International Transmission of US Monetary Policy Shocks: Evidence from VAR's. Journal of Monetary Economics, 48(2), 339-372.

Kim, S., (1999). Do monetary policy shocks matter in the G-7 countries? Using common identifying assumptions about monetary policy across countries. Journal of International Economics, 48, 387-412. 
Kim, S., and Roubini, N., (2000). Exchange rate anomalies in the industrial countries: A solution with a structural VAR approach. Journal of Monetary Economics, 45, 561-586.

Kose, M. A., Otrok, C., \& Whiteman, C. H. (2003). International Business Cycles: World, Region, and Country-SpeciPc Factors. American Economic Review, 93, 1216-1239.

Liu, P., Mumtaz, H., \& Theophilopoulou, A. (2014). The Transmission of International Shocks to the UK. Estimates Based On A Time-Varying Factor Augmented Var. Journal of International Money and Finance, 46, 1-15.

Lubik, T. A., \& Schorfheide, F. (2007). Do Central Banks Respond to Exchange Rate Movements? A Structural Investigation. Journal of Monetary Economics, 54(4), 1069-1087.

Ludovic, G., \& Rebillard, C. (2015). Towards Recoupling? Assessing the Global Impact of a Chinese Hard Landing through Trade and Commodity Price Channels. Working. Paper 562, Paris: Banque de France.

Lumsdaine, R. L., \& Prasad, E. S. (2003). Identifying the Common Component of International Economic Fluctuations: A New Approach. The Economic Journal, 113, 101-127.

Mumtaz, H., \& Surico, P. (2009). The Transmission of International Shocks: A Factoraugmented VAR Approach. Journal of Money, Credit and Banking, 41(s1), 71-100.

Peersman, G. (2004). The Transmission of Monetary Policy in the Euro Area: Are the Effects Different Across Countries? Oxford Bulletin of Economics and Statistics, 66(3), 285-308.

Pesaran, M. H. (2006). Estimation and Inference in Large Heterogeneous Panels with a Multifactor Error Structure. Econometrica, 74(4), 967-1012.

Pesaran, M. H., Schuermann, T., \& Weiner, S. M. (2004). Modelling Interdependencies Using a Global Error-Correcting Macroeconometric Model. Journal of Business \& Economic Statistics, Vol. 22, 129-162.

Pesaran, M. H., Schuermann, T., \& Weiner, S. M. (2004). Modelling Regional Interdependencies Using a Global Error-Correcting Macroeconometric Model. Journal of Business \& Economic Statistics, 22, 129-162.

Pesaran, M. H., Shin, Y., \& Smith, R. (2000). Structural Analysis of Vector Error Correction Models with Exogenous I (1) Variables. Journal of Econometrics, 97, 293-343.

Rabanal, P., (2003). The Cost Channel of Monetary Policy: Further Evidence for the United States and the Euro Area. IMF Working Paper, WP/03/149.

Rabanal, P., (2007). Does inflation increase after a monetary policy tightening? Answers based on an estimated DSGE model. Journal of Economic Dynamics and Control, 31, 906-937.

Ravenna. F., and Walsh, C., (2006). Optimal Monetary Policy with the Cost Channel. Journal of Monetary Economics, 53, 199 -216. 
Rey, H. (2015). Dilemma Not Trilemma: The Global Financial Cycle and Monetary Policy Independence. NBER Working Paper No. 21162.

Ricci-Risquete, A., \& Ramajo-Hernández, J. (2015). Macroeconomic Effects of Fiscal Policy in the European Union: A GVAR Model. Empirical Economics, 48(4), 1587-1617.

Sims, C., (1992). Interpreting the Macroeconomic Time Series Facts: The Effects of Monetary Policy. European Economic Review, 36, 975-1000.

Stock, J. H., \& Watson, M. W. (2002). Macroeconomic Forecasting Using Diffusion Indexes. Journal of Business and Economic Statistics, 20, 147-162.

Svensson, L. E., \& van Wijnbergen, S. (1989). Excess Capacity, Monopolistic Competition, and International Transmission of Monetary Disturbances. Economic Journal, 99(397), 785-805.

Tillman, P., (2008). Does the Cost Channel Explain Inflation Dynamics? Journal of Economic Dynamics and Control, 32, 2723-2744.

Uhlig, H., (2005). What are the effects of monetary policy? results from an agnostic identification procedure. J. Monet. Econ, 52, 381-419. 